\title{
Chapter 5 \\ Direct and Indirect Investments in the Energy Sector
}

This chapter focuses on financial investments, coming either from public or private asset managers and institutions. It has two main targeted readers (without any exclusion): (i) public and private capital providers, with the objective of presenting traditional and alternative financial instruments and schemes capable to align risk-return profiles of several investment opportunities in the clean energy sector, (ii) project developers, in order to increase awareness of the financial mechanisms available in the market.

The first part of this chapter starts by highlighting the role of public finance in the allocation of private capital towards clean energy companies and projects. Thereafter, it presents traditional and alternative direct financial instruments, with the aim of giving a comprehensive overview of the solutions that can foster the financing of clean energy access. In addition, it exposes the role of special-purpose investment vehicles.

The second part of this chapter focuses on alternative financial structures able to enhance financial flows towards clean energy access in sub-Saharan Africa, including blended finance, crowdfunding platforms and structured finance. Finally, the last sub-section is dedicated to the financing of large and complex energy projects, as well as the mechanisms available to decrease the risk perception and foster their funding.

In addition to energy policies and targeted initiatives, the public sector also uses its financial resources to directly or indirectly fund clean energy activities. Apart from subsidy schemes, public institutions may use additional financial instruments and mechanisms as well as collaborate with private actors through public-private partnerships (PPPs).

As previously reported, public money will not be sufficient to bridge the financial gap associated with the access to clean energy in sub-Saharan Africa. Thus, private capital providers should be encouraged to invest in related initiatives. Moreover, 
private investors have a broad set of financial schemes at their disposal to meet the requirements of the supply and demand of capital.

\subsection{The Role of Public Finance}

Public financial institutions have a crucial role to play in the financing of clean energy access in sub-Saharan Africa, especially by paying the way for the private sector and creating an enabling investment climate.

Public financial resources are used to develop and implement public policies and regulations as well as specific programs supporting the growth of the clean energy sector. In addition, the public sphere directly invests in public and private initiatives supporting energy access, mainly through grants and (concessional) lending. On top of that, recent years have seen the deployment of innovative financial structures and mechanisms, such as guarantees, liquidity facilities and derivative instruments, aimed at addressing specific investors' concerns and leveraging private capital (IRENA, 2016). Even though some projects may still require direct public funding, an increasing use of mobilisation tools is important considering the limited availability of public money. Indeed, they are necessary to bridge the financing gap in the access to clean energy in sub-Saharan Africa.

Public funding sources include government spending, multilateral agencies, public export agencies and climate finance institutions. All can invest in publicly and privately owned organisations. Those public finance entities should provide capital to underinvested sectors that generate a positive economic, social and environmental impact, using various financial instruments. They usually offer funds on concessional terms, thus reducing the overall cost of capital for investees. In addition, the presence of public money may also decrease the risk perception associated with a project or a company and therefore catalyse private investors.

\subsection{Traditional and Alternative Financial Instruments}

This subsection presents traditional financing schemes (grant, debt and equity financing) used by capital providers to fund energy projects and companies. Those financing instruments are generally used by public institutions, commercial and investment banks as well as institutional investors.

In addition, alternative instruments can be mobilised to finance clean energy initiatives in sub-Saharan Africa, as they present specific features that may be well-suited for specific financial structures and projections. Indeed, they can adapt to particular constraints and cash-flow forecasts, thus reducing pressure on financial statements in the short run. Moreover, this flexibility may give time and space to project developers to understand their markets, develop projects responding to customer needs and 
validate their business model for subsequent rounds of financing. Alternative financial instruments may bear early-stage risks and prepare for scaling, thus catalysing mainstream capital at later development stages. This is particularly important as behavioural changes may take long and a significant part of potential customers are poor in sub-Saharan Africa. Finally, those alternative financing structures provide additional options for investors to exit their investments, essential in illiquid sectors and underdeveloped capital markets.

Nowadays, alternative financial instruments are underutilised in many sectors, mainly because both investors and investees are not familiar with those innovative financial structures or not aware of their existence. Furthermore, certain jurisdictions may not be adapted to their application. However, they have the potential to achieve a win-win situation, especially for off-grid and clean cooking companies. Indeed, they have the potential to match the supply and demand of capital and provide more flexibility by aligning financial obligations and capabilities over time. Accordingly, they offer additional options to fund companies, in particular those without a sufficient track record for traditional debt investors such as commercial banks.

It is important to mention that the development and use of new financial products and schemes must strike the right balance between necessary innovation and familiarity to capital providers. In addition, common standards as well as supporting policies and regulations are required in order to reach a significant scale.

\subsubsection{Grants}

Grants can fund initiatives at different development stages. Since they do not involve interest rate, they represent an entry of capital free of charge, thus de-risking the aided project. Furthermore, grants may encourage mission alignment and help achieving impact objectives.

Grant funding may support preliminary activities of a project. At later stages, it provides the opportunity to set lower selling prices and/or affordable tariffs and connection fees for end-users. Moreover, grants may cover financing needs of technical assistance programs as well as awareness campaigns.

Grants can be recoverable, meaning that all or part of the principal must be repaid to the granter at a specific moment in time. Another form of grant funding which is increasingly prevalent in international climate finance is result-based financing. This ex-post funding scheme bases the distribution of funds upon the achievement of predefined results such as serving hard-to-reach segments or entering new market(s). Therefore, it provides strong incentives for recipients to reach those objectives, while letting them autonomy and flexibility on the means. At the same time, grantees must have access to upfront capital to be able to respond to those incentives, which may be challenging in certain cases.

In addition, public finance institutions as well as private capital providers may use convertible grants, giving the possibility to shift from grant funding to interestbearing loan financing once a particular milestone is reached (i.e. feasibility study 
completion, pilot project achievement, financial closure, number of customers served). Therefore, it offers the opportunity to support projects during phases with insufficient capacities to cover the entirety of financial expenses, without removing the potential to benefit from interest payments should the desired outcome materialise. Moreover, public convertible grants may facilitate access to private capital by reducing financial constraints before conversion and accompanying projects towards the realisation of specific objectives. Convertible grants are part of the set of financial instruments used by the Electrification Financing Initiative (ElectriFI ${ }^{1}$ ), an impact investment facility funded by the European Union with the mission to support the access to clean energy in developing countries.

\subsubsection{Debt-Like Instruments}

Debt financing is commonly used by capital providers and may include either traditional or concessional terms. The latter offers advantageous financial conditions, including below-market interest rates, long-term tenors and/or longer grace periods.

As an example, ResponsAbility, an impact investor with headquarters in Switzerland, proposes flexible debt financing solutions for energy access companies active in Africa and Asia Pacific (ResponsAbility, 2020). They include flexible ticket sizes, maturities ranging from 6 to 36 months, funding in various currencies, as well as disbursement and repayment structures tailored to cash-flow projections.

A market-based lenders' approach usually requires the provision of collaterals, an adequate debt to equity ratio and an acceptable debt service coverage ratio (DSCR), preventing the use of debt-like instruments for many early-stage and growing companies. In contrast to traditional fixed repayment schemes, certain lenders may include additional conditions and concessionary terms in order to adapt to financial projections. Indeed, debts can be subordinated, offer longer grace periods and/or bullet payments, as well as reduce their collateral requirements. Those debt-like instruments are well-suited for companies at development stage, when scaling requires additional funding but cash-flows do not necessarily cover financial obligations at the moment of investment. Moreover, they avoid dilution for project developers, may optimise fiscal positions and are usually less expensive than equity-like instruments.

Subordinated debt and shareholder loans may be provided to clean energy projects or companies, with the objective of enhancing credit ratings and catalysing private capital. Also known as junior securities, subordinated debts are unsecured loans that are repaid after senior debt securities, meaning they rank below with respect to claims on assets or earnings. A shareholder loan is an interest-bearing debt provided by the owner(s) of a company in order to cover temporarily cash shortage and remove the necessity to seek external financing in the short run. By having a lower cash-flow priority in the capital stack, subordinated debts and shareholder loans can

\footnotetext{
${ }^{1}$ For more information: https://www.electrifi.eu.
} 
thus catalyse private capital and reduce the cost of financing as they decrease part of the liquidity risk for senior debt investors.

Like for grant funding, lenders may use convertible loans to finance projects in the clean energy sector. This mezzanine ${ }^{2}$ instrument offers the option to convert the outstanding balance into an equity investment during a period of time and at predefined conditions, usually when an agreed milestone is reached (the trigger). A SAFE is in many aspects similar to a convertible note, with the difference that the loan bears no interest. The potential upside returns of those two debt-like instruments may be attractive for private investors.

Private capital providers may use convertible loans to fund companies at seed or early stages as well as for bridge financing, ${ }^{3}$ usually converting at the next investment round. Convertible loans generally do not require an immediate payment of interest, but rather the latter get accrued and converted to equity, thus reducing pressure on cash-flows in the short term. Moreover, the execution of convertible notes is usually faster than equity financing, as an agreement on valuation is not needed at the time of the investment.

Similarly, convertible loans can be used by public institutions to finance earlystage activities, thereby assuming development risks. For instance, in case a project is successfully developed and thus catalyses private capital for construction, operations or scaling, the public investment is repaid as a traditional debt and private investors benefit from a more stable situation. Otherwise, project developers are diluted but avoid going bankrupt as the debt is converted to equity.

Finally, revenue-based financing is a debt mezzanine instrument, increasingly used by investors, where a percentage (fixed or variable) of the investees' revenues ${ }^{4}$ is used as source of return for lenders. This structure, thus, follows the seasonality of a company and is designed to stop paying investors when total payments have reached a prenegotiated return, expressed as a multiple of the principal. Company's payments may be made monthly, quarterly or yearly, depending on the lending agreement. This financial instrument is particularly well-suited for companies with existing operations and revenues streams, looking for financing for scaling but that do not fulfil all requirements of traditional lenders such as commercial banks. Moreover, financial expenses associated with this scheme lessen pressure on cash-flows since they are usually based on revenues realised by the company.

\footnotetext{
${ }^{2}$ Mezzanine financing is a layer of financing that fills the gap between senior debt and equity in a company. It can be structured either as preferred stock or as unsecured debt, and it may provide investors with an option to convert to equity interest.

${ }^{3}$ Bridge financing is an interim financing option used by companies and other entities to solidify short-term positions until long-term financing can be arranged. It can take the form of debt or equity. ${ }^{4}$ In the case of a demand dividend (in many aspects similar to revenue-based financing), the percentage is on operating cash-flows rather than on the revenues.
} 


\subsubsection{Equity-Like Investments}

Public finance institutions may directly hold shares of companies, being a minority or majority investor. Moreover, equity-like instruments allow public authorities to participate in the management of investees, giving the opportunity to align enterprise strategies with national public objectives.

Similarly, equity financing can also be used by private investors, involving the purchase of common or preferred stocks. The equity-financing process can be done directly, thus applying to private companies, or through a secondary market, referring to companies listed on an exchange.

Equity investors may include special features in order to provide more flexibility to their portfolio companies and adapt their expected returns to the risks taken, ranging from warranties to buy back options.

Redeemable shares and performance aligned stocks are types of equity securities where the company buys back the outstanding shares of an investor over time or at a specific moment in time. Payments are divided by a ratio of dividend payments and share redemptions. They can be triggered by pre-agreed terms such as a percentage of revenues, redemption rights or repurchase schedules, and negotiated at the time of investment, thus offering a structured exit ${ }^{5}$ for capital providers. According to the financing contract, shares can be repurchased on monthly, quarterly or yearly basis as well as with a bullet payment at maturity, thereby adapting to the company's financial forecasts.

\subsection{Special-Purpose Investment Vehicles}

Financial institutions can develop special-purpose investment vehicles focusing on specific development objectives such as clean energy access. The pool of money can either come from public, private and blended sources.

Those funds may be used to invest directly in projects and companies as well as to provide guarantees targeting specific investment risks or third-party collateralization, thus improving bankability. More information regarding the use of special-purpose vehicles to mitigate certain investment risks is provided in the following sections.

Nowadays, the clean energy sector presents a set of interesting businesses and investment opportunities with a potential for attractive financial returns. Therefore, financing vehicles dedicated to the access to clean energy are more and more emerging. For instance, Energy Access Ventures $\left(\mathrm{EAV}^{6}\right)$ is a hands-on investor in the next generation of smart infrastructure companies in sub-Saharan Africa. EAV I, a $\$ 75$ million fund, focuses on distributed energy enterprises.

\footnotetext{
${ }^{5}$ Other methods exist to exit an equity investment: corporate acquisition, equity sale on the secondary market, initial public offering (IPO). However, they may sometimes be particularly difficult to apply in current sub-Saharan African contexts.

${ }^{6}$ For more information: https://eavafrica.com.
} 


\subsection{Alternative Financial Structures}

This following subsection focuses on alternative financial mechanisms and structures, adapted to the specificities of certain investment opportunities in the clean energy sector. Indeed, in many situations, project developers and entrepreneurs require innovative schemes to fulfil their financing requirements. This necessity may come from different factors, such as early development stages and the types of business or the risk-return profiles.

\subsubsection{Blended Finance}

Blended finance is a structuring approach that uses public or philanthropic capital with the aim of increasing private investments in development and sustainable objectives (Fig. 5.1) (Convergence, n.d.). It allows different capital providers to invest together, while targeting their own goals, whether financial returns, positive social and environmental impact or a combination of both.

This structure can be applied to various types of financial transactions, including special-purpose funds, direct investments and other facilities. Blended finance is primarily employed when the expected financial returns are considered as too low compared to the perceived risks for private investors. Public or philanthropic capital is

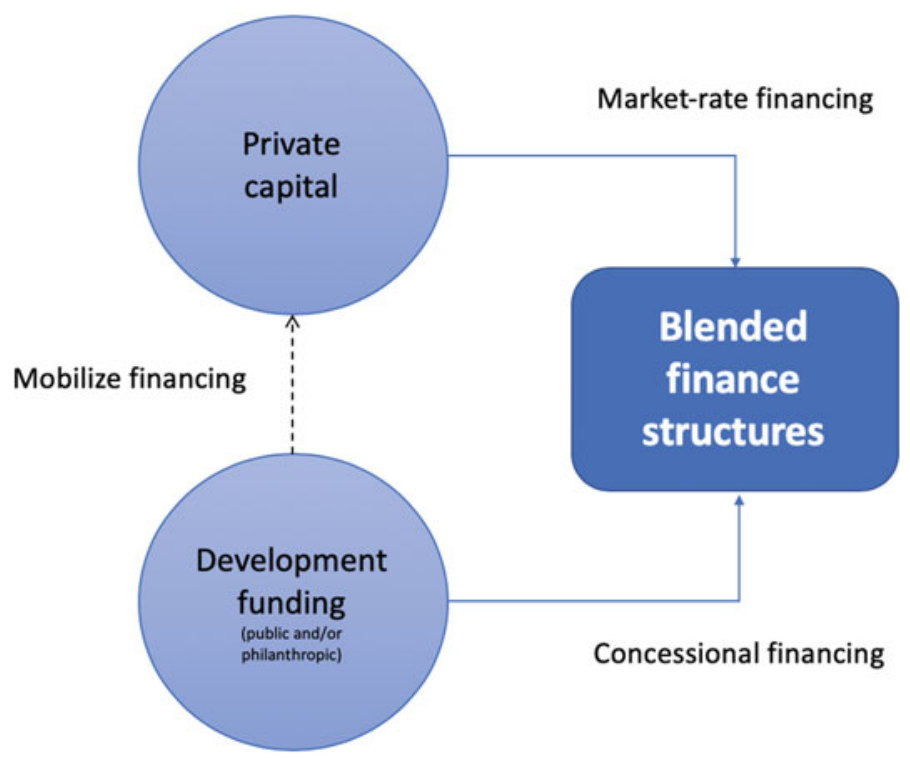

Fig. 5.1 Blended finance. Source Authors' elaboration, based on https://www.convergence.finance/ blended-finance 
then used to reduce the risk perception through concessional financing ${ }^{7}$ or guarantees, thus crowding in investments on commercial terms and helping direct private investments towards social and environmental goals. Furthermore, the mix of concessional and commercially oriented capital increases the competitiveness of clean energy solutions as well as enables acceptable and affordable tariffs for end-users.

Considering the limited amount of public and philanthropic funds, they must be deployed strategically to unlock the potential of markets and sectors perceived as risky by commercially oriented capital providers. Multilateral agencies and development banks are particularly well-positioned to scale up the deployment of blended finance, using their resources and expertise as well as their relationships with the international investment community.

Blended finance provides the opportunity to share skills, experience and network as well as cumulate resources and capabilities. Similarly, this approach enables a better management of risks associated with a financial transaction. Moreover, it allows the deployment of tailored financing structures through mechanisms and instruments used by public and private actors.

Even though blended finance is an interesting mechanism to leverage private capital and expertise, its use remains limited across the African continent and is mainly concentrated in a few countries (Izuwah and Rana, 2018). As a matter of fact, some existing barriers hamper its development and implementation, including among other:

- Inappropriate legal and regulatory frameworks

- Corruption

- Political and economic instability

- Lack of suitable skills and experience among both public and private players

- Lack of cooperation, poor definition of roles and responsibilities

- Time-consuming and complex processes

- Lack of investment-ready projects suitable for blended finance

- Lack of public financial and fiscal incentives, such as sovereign guarantees, able to catalyse private actors in blended finance structures.

Source: Bindzi Zogo (2017) Dentons (2018), Olusola Babatunde et al. (2015), Vallée (2018)

In order to overcome those barriers, public financial institutions may start with small projects to gain experience in Africa, before embarking on larger ones based on the lessons learned. Moreover, public authorities can improve risk-return profiles of targeted projects by mitigating some of the associated risks, thus improving attractiveness for the private sector. As an example, the government of Pakistan issued a wind risk guarantee to compensate investors when wind speed is unfavourable compared to a predefined benchmark (Izuwah and Rana, 2018).

In addition, some of those barriers can be overcome with the support of multilateral agencies providing advisory services and technical assistance in the structuring, execution and management of blended finance schemes.

${ }^{7}$ Through cost, structure, terms, rank or a combination. 
Some encouraging examples of blended finance structures and public-private partnerships have started to emerge across the sub-Saharan African region. For instance, the Rwandan government collaborated with several private companies to deploy off-grid solar systems in remote locations, providing access to affordable electricity to approximately 600,000 rural households (Cornell University, 2018). Moreover, the United Nations Development Programme (UNDP) partnered with the Swedish impact investment platform TRINE, with the objective of contributing to the achievement of SGD 7, initially focusing on Kenya, Rwanda Nigeria, Tanzania and Zambia (UNDP, 2018).

\subsubsection{Crowdfunding Platforms}

Crowdfunding platforms have surged in popularity in recent years and are used as funding options in various sectors. They have started to emerge after the 2008 financial crisis, in response to the difficulties faced by many enterprises attempting to raise private capital.

Those virtual platforms provide small-scale and retail capital providers with the opportunity to invest little amount of money into private companies, initiatives and ideas. Therefore, crowdfunding platforms hold the potential to democratise climate investments, by increasing awareness and encouraging public participation in the realm of social and environmental change.

In addition, they offer an alternative potential funding option for private organisations as well as a diversification of financing, outside the traditional sources of capital. Without representing a disruption or competition to larger investors, crowdfunding platforms can potentially increase the amount of finance available for small to medium clean energy projects. They are particularly well-adapted to overcome the initial financing gap in investments that do not required large ticket sizes and due diligence processes (Globalfields, 2020).

Many types of crowdfunding exist, but generally speaking they fall into two broad categories: non-investment and investment crowdfunding. Non-investment crowdfunding refers to funding driven by donations and rewards, excluding financial returns expectations. This category includes systems using recoverable grants such as the $\mathrm{Kiva}^{8}$ platform which provides loans that need to be paid back without interest charges. By contrast, investment crowdfunding usually involves larger sums and includes both debt and equity financing. They are regulated by public authorities, generally unlike non-investment platforms. For project developers, it is important to select the right platform when using crowdfunding, focusing of the adequate type(s) of financial instruments and targeted sector(s).

This financing solutions can be applied to clean energy access, by providing funds to early-stage and established projects and companies. Indeed, several platforms

\footnotetext{
${ }^{8}$ https://www.kiva.org/businesscenter/crowdfunding-with-kiva.
} 
Table 5.1 Examples of companies that raised capital through crowdfunding platforms

\begin{tabular}{l|l|l|l|l}
\hline Company & $\begin{array}{l}\text { Amount raised } \\
\text { (USD) }\end{array}$ & Platform & Campaign type & Country of activity \\
\hline WakaWaka & $1,266,166$ & Oneplanetcrowd & Equity & Various \\
\hline Buffalo grid & 719,550 & Crowdcube & Equity & Uganda, India \\
\hline $\begin{array}{l}\text { Mobile } \\
\text { Solarkraftwerke } \\
\text { Africa }\end{array}$ & 384,615 & Bettervest & Debt & Mali \\
\hline SunTransfert & 263,958 & Bettervest & Debt & Kenya \\
\hline Vitalite & 111,000 & Trine & Debt & Zambia \\
\hline SimGas & 111,000 & Lendahand & Debt & Tanzania \\
\hline
\end{tabular}

Source Authors' elaboration, based on E4I (2017)

specialised in renewable resources and energy access have started to appear (i.e. MChanga,${ }^{9}$ Energise Africa, ${ }^{10}$ Trine, ${ }^{11}$ Bettervest, ${ }^{12}$ Triodos Crowdfunding, ${ }^{13}$ etc.). Even though the sums invested can reached millions of US dollars, crowdfunding platforms are well-adapted to small-scale energy projects, such as mini-grids, standalone systems and clean cooking companies.

Between 2015 and June 2019, \$77 million have been raised for energy access through crowdfunding, with capital coming primarily from Europe, Japan and the USA (Cogan, 2019; E4I, n.d.). Crowdfunding platforms are supported by a new generation of investors, mainly Millennials, concerned with using their financial resources in a different way, aligning their investments with their personal values.

Even though this number is impressive, it is still far from the total financing gap associated with energy access. Nowadays, crowdfunding platforms are still underutilised to finance projects aimed at fostering the access to clean energy, mainly because this practice is still little known, and thus many project developers do not think about this alternative source of funding to raise private capital (Cogan, 2019).

However, several energy companies active in sub-Saharan Africa have successfully raised capital through crowdfunding platforms (see Table 5.1). In addition, other energy companies targeting other markets have raised significant amount of money thanks to crowdfunding. One of them is GoSun, which has raised over \$2.6 million for the development of a diverse portfolio of energy projects, ranging from clean cooking devices and solar-powered coolers, to a water purification system (Casey, $2020)$. Another example is Allpowers, a firm that rose close to $\$ 1.5$ million $(14,800 \%$ of its funding target) for the commercial production and distribution of a massive 1.287 Wh solar-powered charger (ibid.). Those two success stories suggest that clean

\footnotetext{
${ }^{9}$ https://www.changa.co.ke.

${ }^{10} \mathrm{https}: / / \mathrm{www}$. energiseafrica.com.

${ }^{11} \mathrm{https}: / /$ trine.com.

${ }^{12} \mathrm{https} / / / \mathrm{www} \cdot$ bettervest.com/en/.

${ }^{13} \mathrm{https} / / /$ www.triodoscrowdfunding.co.uk.
} 
energy projects have the potential to raise considerable amount of money through crowdfunding.

Crowdfunding presents several advantages, such as the opportunity to have access to a large pool of potential investors, the ability to validate a project as well as the possibility to leverage off/online platforms to gain traction. In addition, project developers usually face less bureaucratic hurdles and may have quicker access to funding compared with the use of traditional financing sources.

Nevertheless, several barriers need to be overcome. The main one is to convince capital providers using unilateral communication. This can be very challenging, especially when presenting unknown technologies and new business models, therefore pushing project developers to be clear, innovative and efficient. Furthermore, investors have to be aware that they fund organisations without the opportunity to realise a solid due diligence process. Finally, regulatory frameworks to protect stakeholders and increase citizen engagement are underdeveloped, even though this trend is rapidly changing.

\subsubsection{Structured Finance}

In order to bridge the gap associated with the financing of clean energy access in subSaharan Africa, investment opportunities in the related sectors have to be available and attractive for "mainstream" investors as well. This means they should have the adequate ticket sizes and risk-return profiles, as well as acceptable transaction costs for both parts of the transaction.

Structured finance mechanisms offer the opportunity to decrease costs related to due diligence processes, improve clarity through standardisation and/or isolate investment risks and financial returns from project originators. Moreover, they may tackle the ticket size challenge linked to small-scale projects and address the issue of illiquidity in certain capital markets.

Therefore, structured finance encompasses financial schemes aimed at responding to the complexity and sophistication of financing needs of certain projects or companies, which cannot be satisfied by conventional financing. In addition, it is used to manage certain investment risks related to complex situations, such as small ticket sizes or future receivables.

Structured finance includes aggregation, securitisation and Yieldco structures. In the subsequent subsections, these different schemes are explained.

\subsubsection{Aggregation}

In order to provide universal access to clean energy in sub-Saharan Africa, different initiatives exist that broadly vary in size and financial needs, ranging from small companies selling solar products in rural areas to large power generation plants connected to the national grid. However, transaction costs and due diligence processes 
tend to be somehow similar, negatively affecting small-scale projects' attractiveness. Moreover, some capital providers may lack internal capacity and/or willingness to assess individual energy projects and structure deals for direct investments in relatively small initiatives.

By pooling several small-scale clean energy projects presenting similar features, aggregation offers various benefits, including (UNDP and ETH Zurich, 2018)

- Increased total financing requirements

- Reduced transaction costs relative to each project

- Access to a broader pool of financing sources and new asset classes

- Diversification benefits across a portfolio of energy projects.

Even though aggregation requires government support (mainly for standardisation) as well as consensus among industry stakeholders, it represents an interesting opportunity to attract the capital of large private investors such as pension funds and insurance companies towards small-scale energy projects.

The Climate Aggregation Platform $\left(\mathrm{CAP}^{14}\right)$ is an initiative implemented by the United Nations Development Programme (UNDP), in partnership with the Global Environment Facility (GEF) and the Climate Bonds Initiative. It has the objective to promote a large-scale use of financial aggregation and reduce the cost of capital for small-scale and low-carbon energy projects in developing countries. The CAP is structured around three core activities: (i) engagement and coordination among industry stakeholders, (ii) development of standardised tools and (iii) technical assistance (IRENA, 2016).

\subsubsection{Securitisation}

Securitisation is a process in which a company pools some of its assets and sells their underlying cash-flows in the form of an asset-backed security (Fig. 5.2). This scheme requires a group of homogeneous assets generating regular and predictable payment streams.

In this financial scheme, the originator creates a special-purpose vehicle (SPV), established as a subsidiary, that can issue asset-backed notes. These notes are secured by the unpaid portions of sales contracts. By transferring specific assets and isolating them into a new legal entity, it separates the associated risks with the ones directly linked to the originator (operational risks related to business expansion for instance).

The assessment of the SPV strongly depends on the nature of the sales contracts, the associated track record (default and delinquency rates), the payment collection system as well as the quality of the customer services and underlying assets.

In the clean energy sector, securitisation is well-adapted to clean cooking companies and distributed energy service companies (DESCOs) using PAYGO systems, leasing products or offering multiple payment schemes. In those specific cases, enterprises have to support the total expenses of energy devices but need to wait several

\footnotetext{
${ }^{14}$ For more information: https://climateaggregation.org.
} 


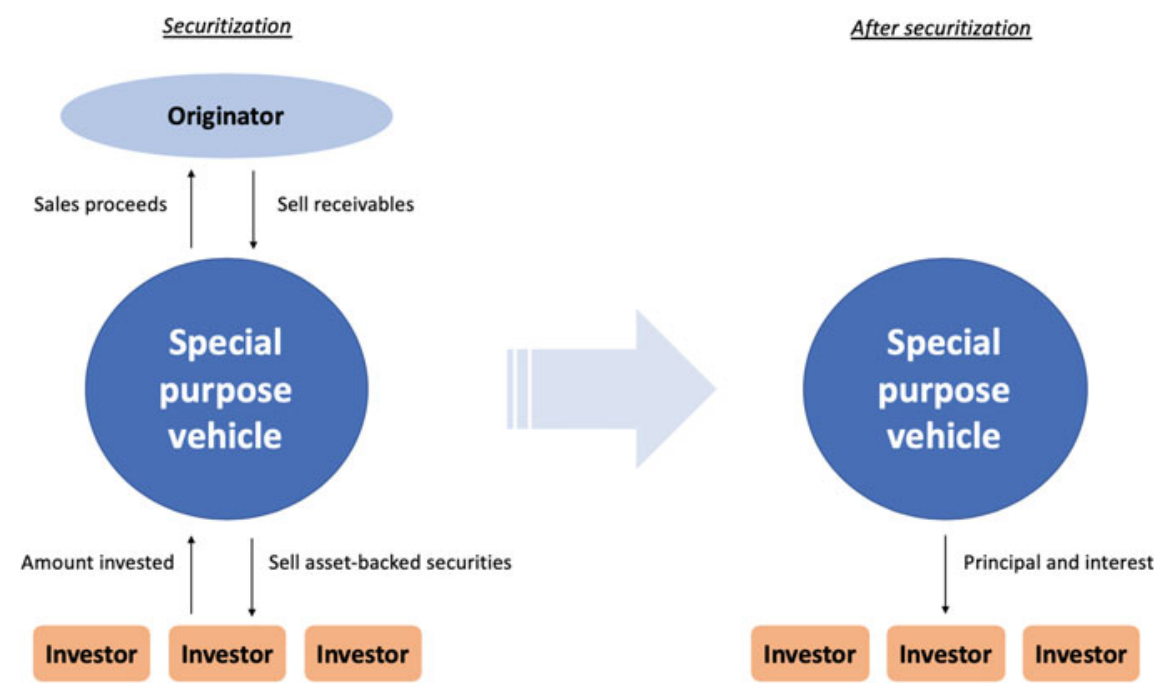

Fig. 5.2 Outline of a securitisation process. Source Authors' elaboration

months or years to fully recover the costs of goods sold. In addition, this period of time increases the exposure of those companies to currency risk when assets are acquired in hard currencies.

Therefore, when a portfolio of customers reaches a significant size, substantial capital is required to cover those asset receivables. While equity-like instruments would not be well-suited, securitisation could be an important cornerstone for the financing of working capital of mature and growing clean cooking companies and DESCOs in sub-Saharan Africa. It provides access to new asset classes and types of investors, mainly large-scale and commercially oriented lenders.

In order to foster the use of securitisation in the clean energy sector, governments need to implement legal frameworks supporting the creation of SPVs. In addition, multilateral agencies and development banks could invest in the riskiest part of the SPV in case several investment tranches are proposed with different risk-reward profiles, thus attracting risk-averse private investors.

However, the use of securitisation in sub-Saharan Africa presents different challenges:

\section{- Large customer portfolio}

A large customer portfolio is needed in order to create an asset-backed security with a significant size and solid track record, able to create economies of scale, cover transaction costs and attract investors. Nevertheless, many companies across the continent have not reached the required size yet.

- High transaction costs

The transaction costs are mainly linked to the SPV creation and may decrease in case securitisation becomes more frequent across sub-Saharan Africa. 
- Limited asset isolation

In the clean energy sector, the originator usually directly collects the receivables. Therefore, a complete separation of the activities is challenging. A vertical disintegration of the clean cooking and off-grid sectors could increase the possibility to isolate assets included in the SPVs.

- Underdeveloped capital markets

Capital markets are needed to support the trading of asset-backed securities on secondary markets. ${ }^{15}$

Nevertheless, securitisation confers important advantages such as

- Opportunity to diversify the financing sources through high-quality debt

Companies may attract new types of investors such as institutional ones. Moreover, they issue asset-backed securities from a subsidiary entity legally separated, with solid track record and predictable cash-flows. Accordingly, investors do not have to bear certain risks linked to the originator as well as development and scaling-related risks. Consequently, the use of this financial scheme may potentially decrease the overall cost of capital in the clean energy sector in the long run.

- Access to financing including hedging instruments

Large-scale investments with underlying cash-flows are more likely to be swapped in hard currencies compared to small ticket sizes.

- Access to financing in local currency

Securitisation may be aligned with investment constraints faced by large local investors such as pension funds and insurance companies.

Solar securitisation for Rwanda is a first-of-its kind initiative that pools loans associated with multiple solar stand-alone systems into a tradable asset-backed security, freeing up capital for market expansion and providing project developers access to more liquid financing (CFL, 2019). The project, still under development in early 2021, is being led by the Development Bank of Rwanda, which has over 15 years of experience in energy finance, and targets three of the largest solar home system companies active in the country. The initial issuance is planned at $\$ 9$ million and should enable the deployment of around 175,000 solar home systems. The instrument will be split into two tranches, with the first one being sold to commercial and retail investors as senior debt. The second tranche, serving as subordinated, will be financed by development finance institutions, providing first loss credit enhancement and downside protection for senior tranche investors.

However, if energy is sold as a service, then clients never purchase or lease assets. It is, for instance, the case of mini-grid companies. Therefore, no fixed financing contracts linked to predictable cash-flows generated by underlying assets can be sold

\footnotetext{
${ }^{15}$ See Chap. 6 for more information on capital market development.
} 
to a SPV. In that case, other financial schemes exist in order to separate specific revenue streams. For instance, Yieldco structures offer this possibility.

\subsubsection{Yieldco Structures}

A Yieldco is a new company created to own operating assets generating predictable cash-flows. The parent company usually maintains an active role, commonly through operation and maintenance (O\&M) contracts or supply agreements, meaning it could thus be replaced in case of bad performance or financial concerns.

Those structures have started to emerge in the US energy sector (i.e. NRG, SunEdison Power) and are therefore built around some unique features based on the country's regulation. Their use in other continents may, thus, require an adaptation of legal frameworks.

A company may allocate all contractual rights related to a group of customers (i.e. service contracts, ownership of used assets, etc.) to a Yieldco. The latter benefits from a higher credit quality since it only bears risks related to operations with existing clients. Construction and expansion risks are carried out by the parent company.

Accordingly, Yieldcos may potentially draw capital at lower cost to finance operating energy assets. They may be funded through debt, equity ${ }^{16}$ or a combination of both, depending on the nature of the underlying cash-flows.

Consequently, a Yieldco structure allows the separation of specific assets from the balance sheet of the parent company and eases the financial analysis for potential investors. In addition, it expands the investor base, providing access to a wider range of capital providers, with different risk appetites.

\subsubsection{Financial Structures for Large and Complex Energy Projects}

This section presents specific financial structures and mechanisms aimed fostering the allocation of capital in large-scale and complex projects, such as infrastructures and power generation plants. Depending on circumstances, they could be applied to smaller energy initiatives as well.

\subsubsection{Off-Balance Sheet Financing}

Also known as project finance, this financing structure offers an interesting opportunity for capital allocation in the clean energy sector. Off-balance sheet financing is commonly used for complex and multiparty projects, requiring substantial funding and characterised by long payback periods.

\footnotetext{
${ }^{16}$ For equity investors, there are also certain tax benefits using this financial scheme.
} 
In contrast to corporate finance where investments are made into companies and thereby consider their entire assets and liabilities, off-balance sheet financing provides capital to a specific project. A special-purpose vehicle (SPV) without previous business record is created, with the sole objective of carrying out the targeted activities.

Project finance limits the exposure of shareholders' resources by separating the specific project from their own balance sheets, thus limiting their financial liabilities. They are only liable up to the extent of their equity investments. Accordingly, lenders' recourse is limited to the SPV's assets in case of default, shifting part of the associated risks from the shareholders to the lenders. Investment criteria are, therefore, different and only focus on the activities of the SPV, its associated risks and potential financial returns.

Off-balance sheet financing is generally a complex and time-consuming process, involving high transaction costs and engaging several stakeholders. The underlying project will have expected revenues and costs, generating cash-flows that will be dedicated to the payments of principals and interests linked to its indebtedness and provide financial returns to shareholders.

Every equity investor is committed to the underlying project and has thus incentives to perform well. Potential project sponsors may include the following actors:

- Public administration

Public authorities may use public tendering processes to select adequate private actor(s) to develop, build and manage a specific project. Furthermore, they can fund part of the related project.

- Private project developers

They are actors bringing not only capital but also skills and experience into the project. They are usually selected through a bidding process managed by public authorities.

\section{- Financial institutions}

Equity investors providing capital to the project.

A typical project finance structure, including the contractual agreements, is represented in Fig. 5.3.

In order to attract private capital providers in this financial structure, projectrelated risks shall be properly identified and allocated during both the precompletion and operational phases. Furthermore, the solidity of the entire network and the interrelations between parties have to be ensured, as it strongly affects the rating of the project and thus influences the cost of its financing.

Off-balance financing is particularly well-suited for power generation plants, a sector in which revenue streams are likely to be fixed by a power purchase agreement (PPA), including when using renewable energy resources. This implies that no revenue is collected during the construction phase for greenfield projects, increasing 


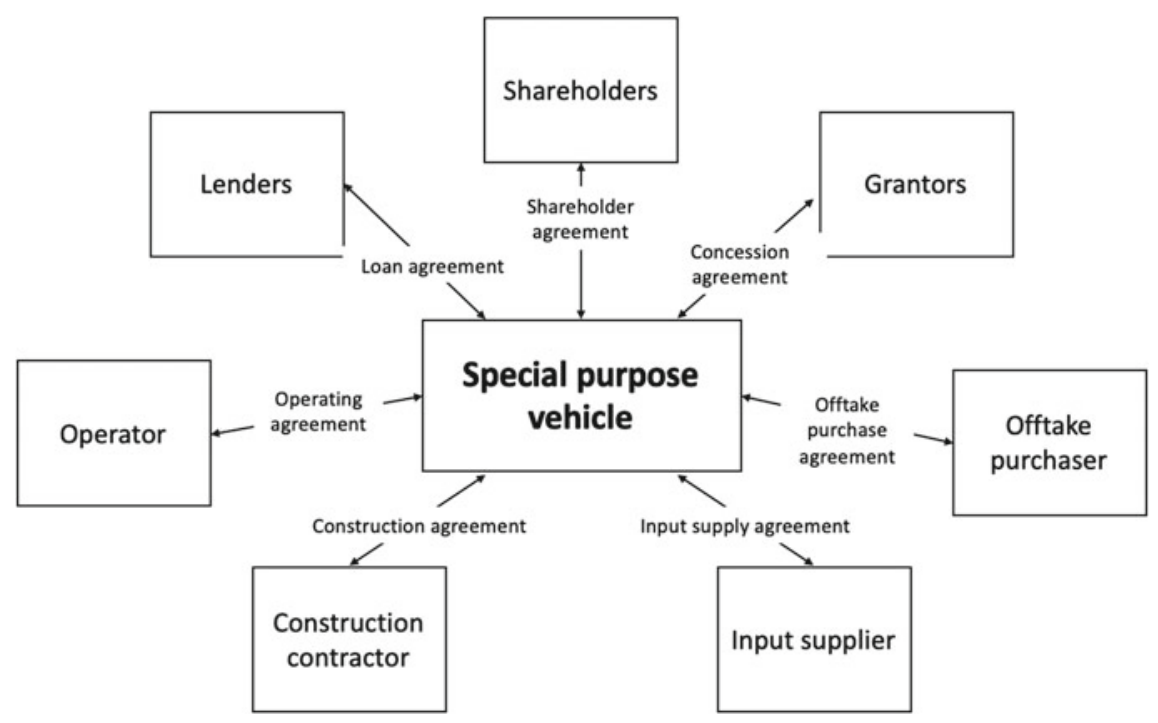

Fig. 5.3 Project finance. Source WB (2016)

the risks for lenders and equity investors, exclusively depending on cash-flows coming from the SPV. Therefore, a specific financial structure needs to be built, able to attract sponsors and debt investors for the financing of the SPV.

So as to keep the retained risk to a minimum level, investment risks can be allocated in two different ways:

- Through the completion of contractual agreements between internal parties

For instance, $\mathrm{EPC}^{17}$ and $\mathrm{O \& M}$ contracts state the required conditions for the construction and operations of the project.

- Through insurance contracts and guarantee instruments with external partners

Other investment concerns such as environmental risk or social acceptance risk may not be allocated through contractual agreements between internal parties. Therefore, the project can work with external public and private companies providing guarantees and insurance products targeting specific risks associated with the underlying project.

\subsubsection{Loan Syndication}

Loan syndication allows the distribution of risks among a group of lenders, therefore limiting each capital provider's risk exposure as well as money invested. This financial structure applies particularly to projects requiring large-scale investments

\footnotetext{
${ }^{17}$ Engineering, procurement and construction contracts.
} 
and perceived as risky. In addition to combining financial resources, syndication contributes to making each participant's skill set and competencies available to a specific project. However, being a time-consuming process, it can be more broadly exposed to changes in economic conditions and political situations.

The participation of multilateral agencies or development banks in loan syndication can be reassuring for other lenders and even decrease the overall cost of borrowing. Indeed, those institutions bring their experience and knowledge of the local context. Therefore, it may facilitate the involvement of local and foreign commercial banks. Moreover, multilateral agencies or development banks may, for instance, lead early rounds of financing using concessional terms, paving the way for private investors through knowledge gained and interest raised.

In addition, development institutions can use B-loan structures in syndicated loans, retaining a portion of the entire loan (A-loan) and selling the remaining part (B-loan) to participant lenders. Through this scheme, clean energy projects can obtain large-scale financing with lower transaction costs and simplified administrative processes by signing a single loan agreement with a public financial institution. Meanwhile, private capital providers engage in a sub-participation with development agencies, instead of directly lending to projects, allowing the public institutions to negotiate on behalf of all lenders. Thence, the latter benefit from higher credit rating, strong ability to manage certain investment risks and close relationships with national governments.

\section{References}

Bindzi Zogo, E. C., Wei, L. P. (2017). Investment motivation in renewable energy: A PPP approach. School of Economics, Wuhan University of Technology, China.

Casey, J. P. (2020). Clean energy Crowdfunding: Successes and failures. Power Technology, Published on July 27, 2020.

CFL (2019). Solar securitization for Rwanda. Climate Finance Lab. Retrieved September 25, 2020 from https://www.climatefinancelab.org/project/solar-securitization/.

Cogan, D. (2019). Too risky for the crowd? Assessing the potential of Crowdfunding for energy access. Next Billion, Guest Articles, October 30, 2019.

Cornell University, INSEAD, and WIPO (2018). The global innovation index 2018: Energizing the world with innovation. Ithaca, Fontainebleau, and Geneva.

Dentons (2018). The emergence of public-private partnerships (PPPs) in the middle East and Africa, May, 2018.

E4I (2017). Crowd power: Can the crowd close the financing gap? Energy4Impact, July, 2017.

Globalfields (2020). Crowdfunding for development and climate finance. Globalfields Insight, November, 2020.

IRENA (2016). Unlocking renewable energy investment: The role of risk mitigation and structured finance. IRENA, Abu Dhabi, 2016.

Izuwah, C., Rana, F. (2018). Infrastructure \& Africa's development-The PPP imperative. Published on Getting Infrastructure Finance Right, January 23, 2018.

Olusola Babatunde, S., Perera, S., Udeaja, C., Zhou, L. (2015). Barriers to public private partnerships projects in developing countries. Northumbria University, UK, November, 2015. https:// doi.org/10.1108/ECAM-12-2014-0159. 
Vallée, M. (2018). PPP laws in Africa: Confusing or clarifying? Published on Getting Infrastructure Finance Right, February 22, 2018.

ResponsAbility (2020). Debt financing, energy access companies in Africa and Asia Pacific. Retrieved October 10, 2020, from https://www.responsability.com/en/energy-access-companiesafrica-and-asia-pacific.

UNDP (2018). UNDP and TRINE partner to scale-up private investment in high-impact energy projects. Posted on April 26, 2018. Retrieved October 7, 2020, from https://www.undp.org/ content/undp/en/home/news-centre/announcements/2018/partnership-to-scale-up-private-invest ment-in-high-impact-energy.html.

UNDP \& ETH Zurich (2018). Derisking renewable energy investment: Off-grid electrification. New York, Zurich, Switzerland: United Nations Development Programme, ETH Zurich, and Energy Politics Group.

WB (2016). Project finance-Key concepts. World Bank Group, September 6, 2016. Retrieved September 10, 2020, from https://ppp.worldbank.org/public-private-partnership/financing/pro ject-finance-concepts.

Open Access This chapter is licensed under the terms of the Creative Commons Attribution 4.0 International License (http://creativecommons.org/licenses/by/4.0/), which permits use, sharing, adaptation, distribution and reproduction in any medium or format, as long as you give appropriate credit to the original author(s) and the source, provide a link to the Creative Commons license and indicate if changes were made.

The images or other third party material in this chapter are included in the chapter's Creative Commons license, unless indicated otherwise in a credit line to the material. If material is not included in the chapter's Creative Commons license and your intended use is not permitted by statutory regulation or exceeds the permitted use, you will need to obtain permission directly from the copyright holder. 